\title{
Service Learning on Inclusive Design: Sidewalk Redesign for Siwalankerto, Surabaya, Indonesia
}

\author{
Gunawan Tanuwidjaja*, Claudia Levina, Cynthia Tandiono, and Christian Tandiono \\ Architecture Program, Petra Christian University, Jl. Siwalankerto No.121-131, \\ Surabaya 60236, Indonesia
}

\begin{abstract}
Public facilities and transportation infrastructure were very important for all residents including Persons with Disabilities (PwDs). Sidewalk should be safe and easy to use for all kind of users, ranging from the elderly, children, and the PwDs including wheelchair users, visual impairment, low vision disability, etc. The sidewalk should be safe, which means it should be inclusive yet also meets the standards. The Service Learning and research program in Petra Christian University's Architecture Program was conducted with literature study, observation, discussion and interviews with users at Siwalankerto street's sidewalks. The design would be implemented in Petra's area in the following year.
\end{abstract}

Key words: Accessibility, disability, inclusive design, sidewalk

\section{Introduction}

\subsection{Background}

The accessibility issue of Persons with Disabilities (PwDs) in the developing countries, like Indonesia, is not highly considered in the development plan. That's why many public facilities such as pedestrian sidewalk are not accessible for PwDs because of the government's limited awareness and budget. Whereas, it have national regulations on the PwDs such as Act no 19 Year 2011 on Ratification of Convention on the Rights of Persons with Disabilities (UU no 19 Tahun 2011 tentang Pengesahan Konvensi mengenai Hak-Hak Penyandang Disabilitas) [1] and Act no 8 Year 2016 on Persons with Disabilities (UU no 8 Tahun 2016 tentang Penyandang Disabilitas) [2].

Indonesian National Statistics Bureau/Biro Pusat Statistik, [3] in National SocioEconomic Survey (Survey Sosial dan Ekonomi Nasional) showed that in 2000, there were 1 460000 of PwDs in Indonesia (0.74\% from 197000000 national population). Currently the PwDs population projected to have reached 6000 000. Therefore, the importance of accessibility forPwDs in public spaces, such as sidewalks, is important.

Surabaya is an Indonesian city with a rapid growth. It could be seen from its facilities and advance transportation system such as highways, flyovers or sidewalks. Unfortunately, some of the facilities are not inclusively accessible for all spectrum of abilities because of several reasons: the limited knowledge of pedestrian planning and design; and limited

* Corresponding author: gunte@petra.ac.id, gunteitb2012@gmail.com 
participation of PwDs in the design, construction, operation and maintenance of the facilities. Similar situation in Indonesia was reported by Komardjaja and Munawar [4, 5]. Hence, a participatory design for sidewalk redesign process was proposed in Siwalankerto area. The sidewalks were developed because of the existence of Petra Christian University (PCU) and some residential nearby. The area was affected by the development of public and governmental facilities, as well as the commercial and services buildings in Ahmad Yani Corridor and Jemur Andayani to Kendangsari Corridor as described by Poerbantanoe [6].

The PCU campuses, the elementary schools, and the Siwalankerto Sub-District Office created high pedestrian flow in the roadside of Siwalankerto area during morning and afternoon, before and after the school time. Thus, the accessible sidewalks were essential in this area. On the other hand, the narrow Right of Way at the main streets of Siwalankerto created high number of pedestrian-related accidents. These had been solved by the culvert development in the Siwalankerto roadside, but the sidewalks in Siwalankerto were not clearly designed, demarcated and regulated to optimize its use.

That's why the Service Learning Course on Inclusive Design was created in Architecture Program and the Siwalankerto's sidewalks redesigning was proposed : to solve the problem. This paper discussed the current condition of the Siwalankerto's sidewalks, the analyses, and the solution proposed in order to redesign the sidewalks based on inclusive design principles. The purpose was to create safe, accessible sidewalks for PwDs.

\subsection{Literature review}

Universal Design Standards, Inclusive Design and also Collaborative or Co-Design were discussed in several papers by Persson, et al. [7] ; Bühler [8]; and Pirinen [9] as the methods to produce a more inclusive design in Architecture.

Levine in The NYC Guidebook to Accessibility and Universal Design, prescribed guideline for exterior planning that are accessible [10]. The accessible standard was selected considering the limitation of developing countries like Indonesia.

Accessible Key Design Goals were stated such as:

i) Designs for outdoor spaces should address users' needs and preferences.

ii) The security and safety of all normal use should be assured.

iii) Provide a continuous path of travel with no obstacles to any user from the site's access points to all site destinations.

iv) Provide security for all users.

v) Provide illumination at all parking areas, passenger loading zones and along pedestrian pathways.

vi) Eliminate hazards at the area

Accessible pathways should be provided with clear width of at least 36 in $(915 \mathrm{~mm})$. Passing spaces at least 60 in by 60 in $(1525 \mathrm{~mm}$ by $1525 \mathrm{~mm}$ ) were to be located at reasonable intervals of $200 \mathrm{ft}(61 \mathrm{~m})$ for accessible pathways with less than 60 in $(1525$ $\mathrm{mm}$ ) clear width. Besides that, the stable, firm, and slip-resistant walking surfaces were also proposed. The height transition of no more than $1 / 4$ in $(6.5 \mathrm{~mm})$ between different flooring surfaces was mandatory. Meanwhile, pathways steeper than 1:20 meet different requirements because they are considered ramps. Cross slopes should not exceeding 1:50. The ramps and curb ramps' level change should not exceed $1 / 2$ in $(13 \mathrm{~mm})$.

Spacing in the gratings had to be greater than $1 / 2$ in $(13 \mathrm{~mm})$ wide and located in one walking direction. Ammout 90 in $(2030 \mathrm{~mm})$ vertical clearance on the pathways had to be provided. Objects mounted to the wall were allowed with bottom edges between 27 in (685 $\mathrm{mm})$ to 80 in $(2030 \mathrm{~mm})$ high from the floor. The objects also should not protrude more than 4 in $(100 \mathrm{~mm})$ from the wall. 
There's a serious safety concerns in traffic intersections for people of all abilities. Improvements to intersections' signage, the condition and length of pedestrian crossings should be done. Accessible criteria of intersections were similar to the ones of accessible pathways.

A curb ramp is a tool that can improve the safety and usability of traffic intersections. In addition to enhance pedestrians' safety, curb ramps permit people using wheelchairs or pushing a stroller to cross the street easier. It need to design curb ramps to improve pedestrians' safety and provide a smooth transition for height changes (from sidewalks to the street). Some accessible criteria of intersection were similar to the ones of accessible pathways. The curb ramp should be provided wherever an accessible pathway meets a curb. The slopes of the curb ramp should not exceed the 1:12 slope. Maximum slopes of adjoining road surfaces also should not exceed 1:20. The clear width of the curb ramp without the flared sides, should be more than 36 in $(915 \mathrm{~mm})$. And flared sides with a maximum flare slope of 1:10 where pedestrians must walk across a curb ramp. All these guidelines actually could be fulfilled in the context of Indonesian sidewalk.

Public Works Minister Regulation no 30/PRT/M/2006 on Technical Guidelines on Accessibility in Building and Environment (PerMen PU no 30/PRT/M/2006) prescribed several guidelines for pedestrian [11]. The pathways should be accessible for pedestrians and wheelchair users independently, safely, easily, and without barriers. The regulation was the surface should be stable, strong, weatherproof, not slippery, without barrier. The maximum slope allowed 1:8 and every $900 \mathrm{~m}$ distance there should be $120 \mathrm{~cm}$ landing area. Resting area should be provided for PwDs. The illuminance of man-made lighting should range between $50 \mathrm{~lx}$ to $150 \mathrm{~lx}$. Maintenance should be conducted. Drainage should be provided at every $1.5 \mathrm{~m}$ intervals. The minimum clear-width of pedestrian was $120 \mathrm{~cm}$ for one-way and $160 \mathrm{~cm}$ for two-ways path. The pathways should be free from trees, poles, drainage holes, or other protruding objects. The curbs should be allowed with $10 \mathrm{~cm}$ to 15 cm height.

Some discrepancy in the regulations were found such as the maximum slope standard. But the latest maximum slope standards were the one that is adopted, which were 1:12 for existing sidewalk or 1:20 for future sidewalk. The other descriptions could be adopted with spatial and economical consideration.

\section{Methodology}

To create the sidewalk design, several steps were conducted, such as:

i) Literature study

ii) Students' simulation as PwDs in Petra Christian University (PCU) area

iii) Observation and documentation in Siwalankerto roadside from PCU main campus (Radius Prawiro Building) towards PCU parking area (ANTA sports field)

iv) Interviews with PCU students and Public Users.

v) Data compilation

vi) Sidewalk redesign based on input fromPwDs, senior persons and students.

First, a literature study was conducted to find out the inclusive principles and standards for designing inclusive sidewalk. Then a simulation involving the student was conducted using wheelchair and blind stick in Petra Christian University pathways. This simulation was done to generate the experience and understanding of PwDs movement.

Observation and documentation were conducted in the Siwalankerto roadside from PCU main campus (Radius Prawiro Building) towards PCU parking area (ANTA sports field). The accessibility level of the existing sidewalks and its problems were analyzed. Furthermore, interview with students and local residents were also conducted with 
purposive sampling method. Based on those steps, the type of activities, needs and responses to Siwalankerto's sidewalk redesign were finally recognized.

A redesign process was conducted in the team. The existing standards were adopted and integrated into the existing context. For a more focused redesign process, a $50 \mathrm{~m}$ length sidewalk path was selected to fulfill the accessible level as prescribed in the aforementioned regulation. Interim presentation with Lecturer, PwDs, Senior Persons and the Public Works Department agent was conducted. Hopefully, a final design would be finalized in August 2017 involving Sub-District Head, Surabaya's Municipality (Public Works Section, Transportation Section, and Civil Defense Section) and the local residents. It is expected that the design would be implemented at the sidewalks in front of PCU.

\section{Results and discussion}

The sidewalks were heavily used by residents, which were mostly women, children and senior citizens. They used the sidewalk intensively during morning between $6 \mathrm{AM}$ to 7 AM, 12 AM to 1 PM, and 5 PM to 7 PM. They normally use the sidewalk to go to school, mosque, traditional market, etc. On the other hand, the PCU Students and Lecturers utilize the sidewalk between 7 AM to 9 AM, 12 AM to 1 PM and 3 PM to 4 PM. They usually walk on the pathways to reach PCU Campus, PCU parking area as well as to buy stationeries, food or other things in the area near PCU.

The sidewalks in Siwalankerto were not accessible for inclusive users, particularly PwDs. This was clearly shown from the observation along the Siwalankerto Street, especially from PCU Main Campus (Radius Prawiro Building) to PCU parking area (ANTA Sports Field). The accessible pathways were found in some areas with minimum clear width of $915 \mathrm{~mm}$. Passing spaces of $1525 \mathrm{~mm}$ by $1525 \mathrm{~mm}$ were present in certain areas. On the other hand, some narrow passages were present. The stable, firm, and slipresistant walking surfaces were not found, some vulnerable gratings were found causing danger to pedestrian.

Several barriers blocked the pedestrians, such as: vehicles parking, irregular trees and electricity poles placement, street vendors and etc. Besides that, cross slopes of the sidewalk exceeded 1:50 causing more danger for pedestrian using crutch, walking stick or wheelchair. Therefore, Persons with Disabilities were found using the street instead of the sidewalk because of this condition.

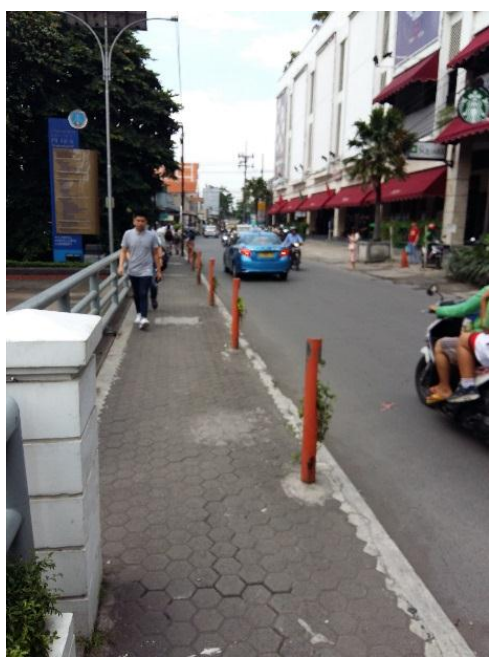


Fig. 1. The accessible pathway were found in front of PCU Main Campus, only there was no curb ramps and pedestrian crossing to assist the PwDs.

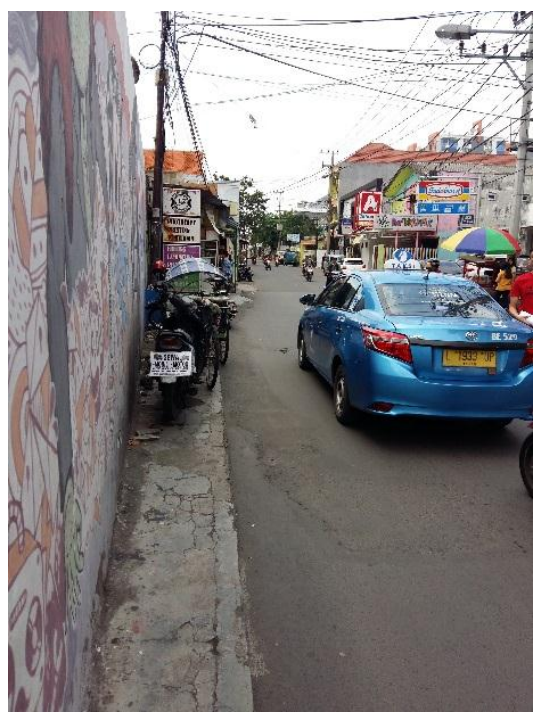

Fig. 2. The narrow and inaccessible pathway, the street's height difference and also parked vehicle and street vendor causing the difficulty to access the street on foot.

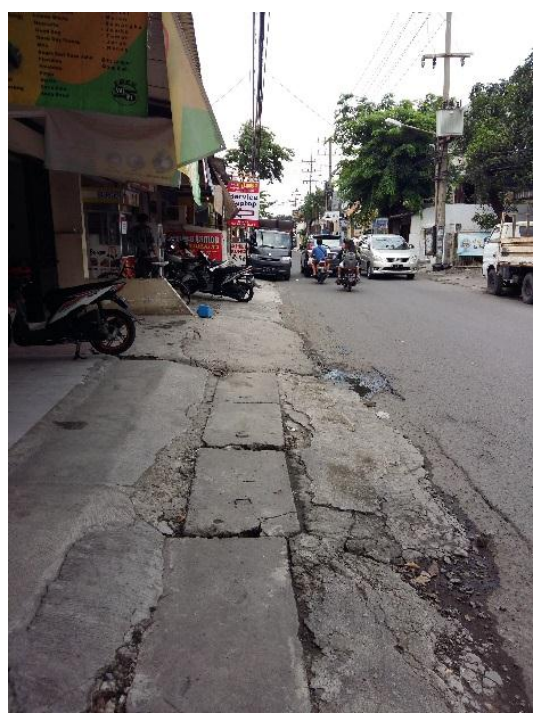

Fig. 3. The accessible pathway were found nearby the PCU Main Campus, but there was no curb ramps and no stable, firm, and slip-resistant walking surfaces. The non PwDs could access but PwDs would find difficulties. 


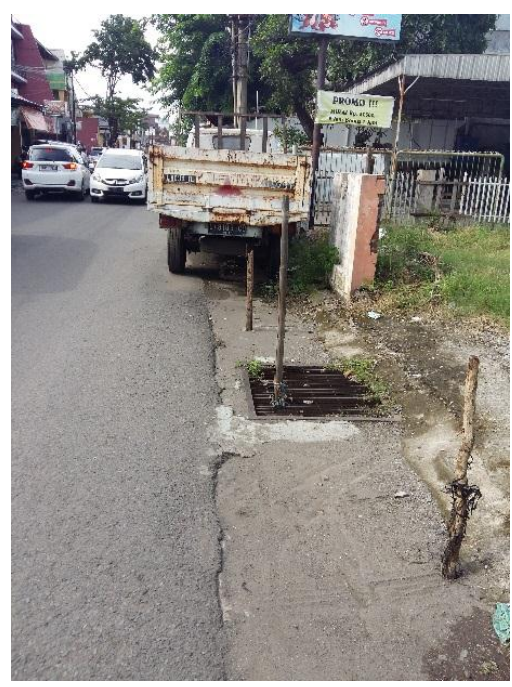

Fig. 4. The narrow and inaccessible pathway, the parked vehicle and vulnerable gratings causing access difficulty for pedestrians.

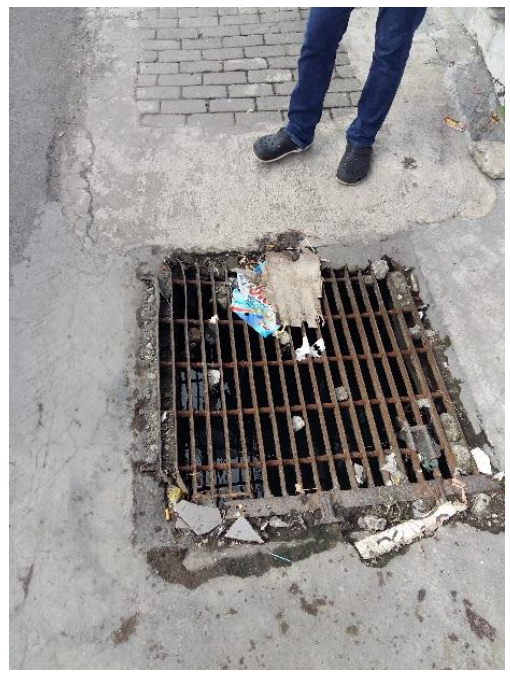

Fig. 5. The vulnerable gratings as one of the obstacles that pedestrians faced at the sidewalks.

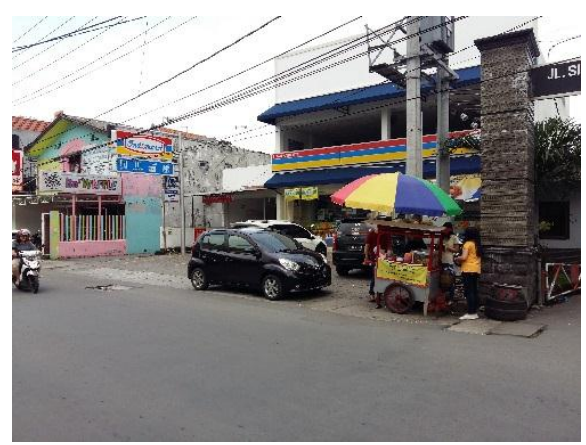

Fig. 6. The narrow and inaccessible pathway, the street's height difference and also parked vehicle and street vendors causing pedestrians to find difficulties while passing this pathway. 


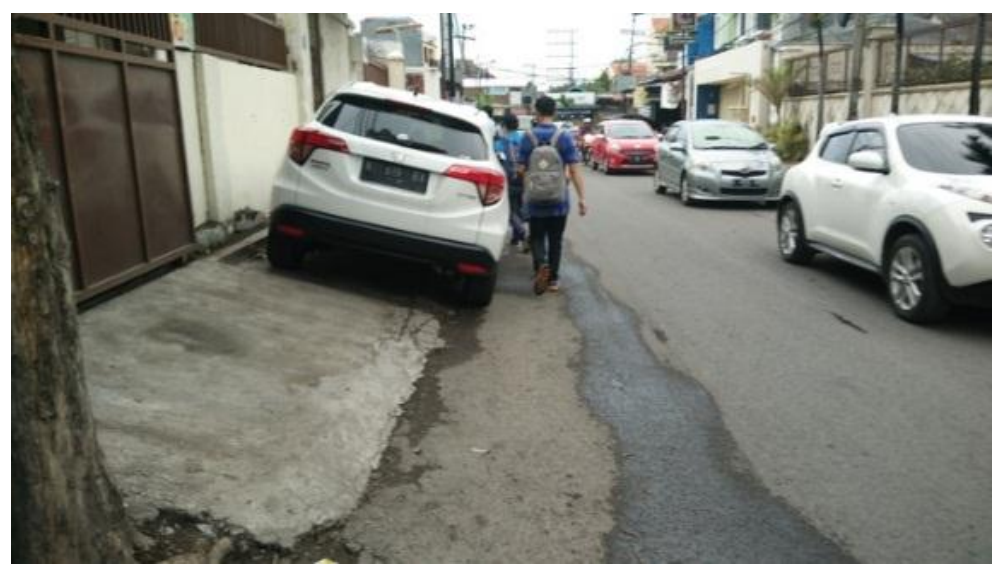

Fig. 7. The sidewalk which cross slopes exceeded 1:50 causing more danger for pedestrians who were using crutch, walking stick or wheelchair.

Pedestrian crossings and intersections were not present because Siwalankerto was designed to serve only the neighbourhood. There was no curb ramp that could enhance the pedestrians' safety. Therefore, the sidewalks needed participatory redesign and management to enhance its accessibility.

Therefore, universal and inclusive design were required to make these sidewalks accessible for all users especially PwDs. The sidewalk design in Siwalankerto was designed based on five inclusive design principles by Tanuwidjaja [12].

The first inclusive design principle was User Centered. It was done with the involvement of users such as: interviews with PCU students and local communities, participatory design with selected resource persons.

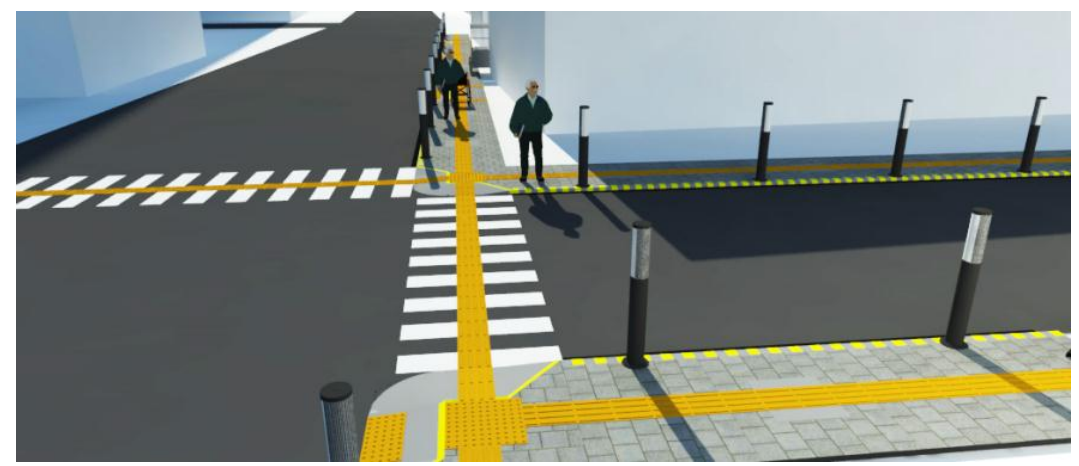

Fig. 8. The pedestrian crossings and intersections connecting PCU Main Campus and PCU East Campus. The guiding paths were provided to assist the visually impaired persons to cross the street. Integrated bollards and lighting were proposed to prohibit irregular vehicle to park on the sidewalk. 


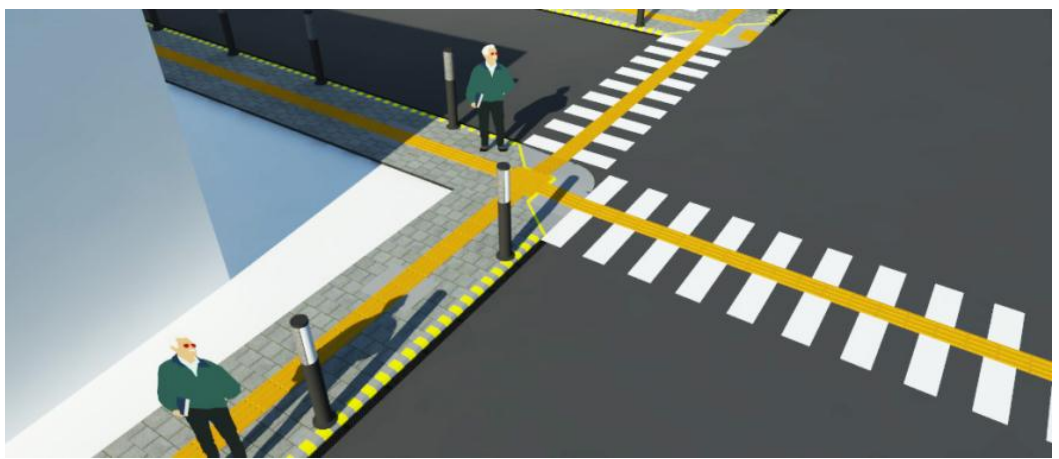

Fig. 9. The pedestrian crossings and intersections connecting PCU Main Campus and PCU East Campus. The curb ramps with 1:12 were provided. The additional guiding paths and speed bumps were added.

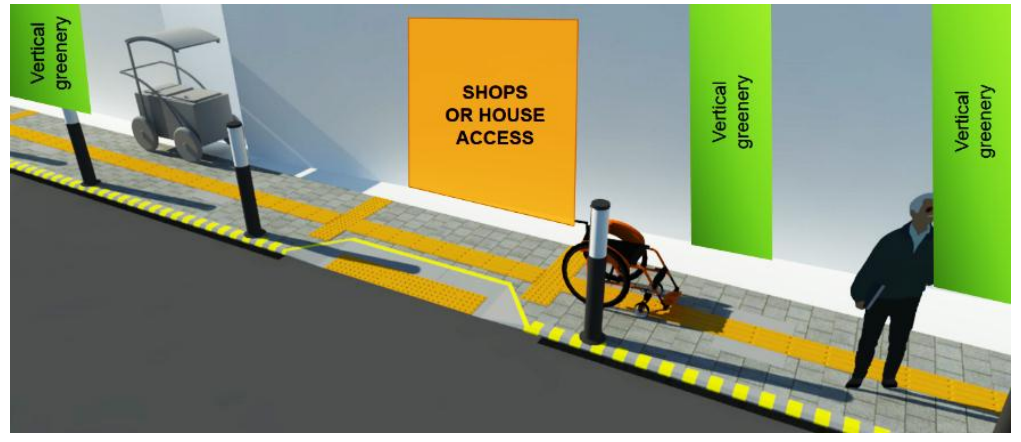

Fig. 10. The crossing point of the sidewalk and existing building access, and some vertical greeneries installed on the existing walls.

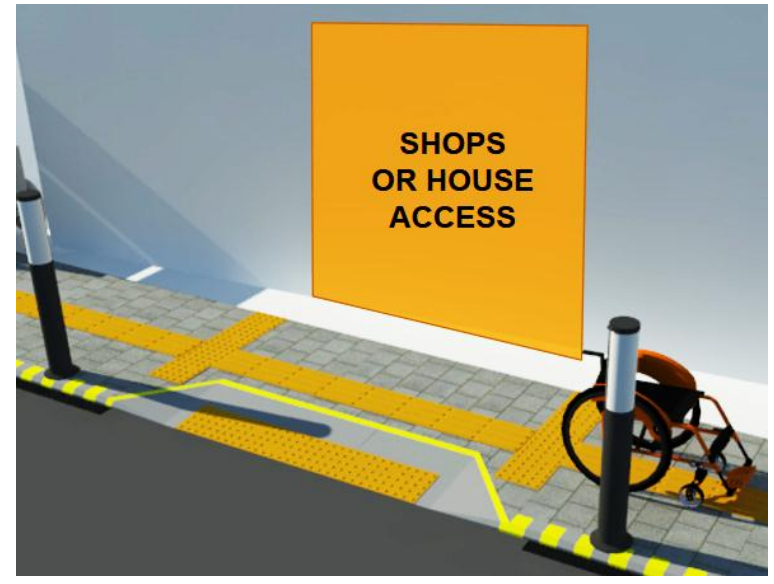

Fig. 11. The details of the guiding path in the crossing of pedestrian and existing building access. The dotted-pattern guiding path guided the visually impaired persons to stop before carefully crossing. Meanwhile the striped-pattern guiding path assisted them to continue the walking direction. 


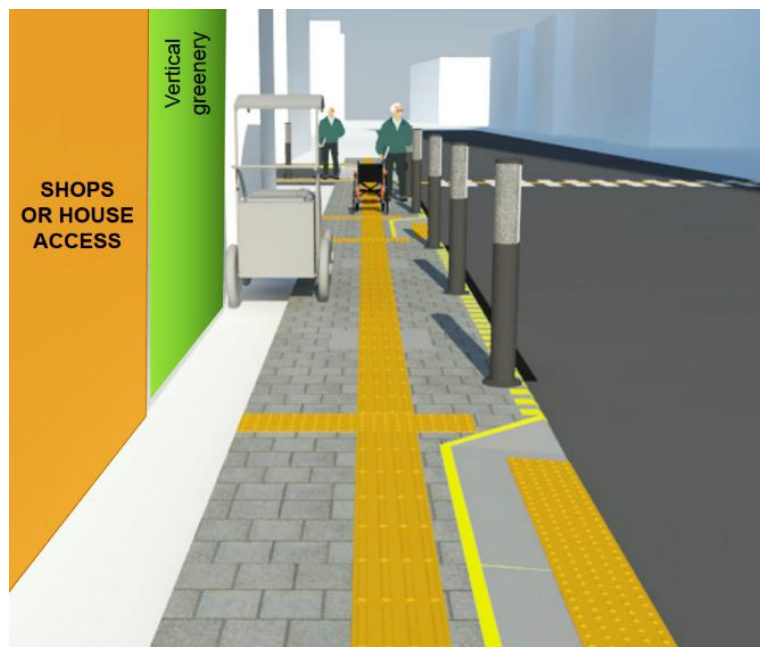

Fig. 12. The total width of $150 \mathrm{~cm}$ was applied in all sidewalks. Meanwhile clear-width of $100 \mathrm{~cm}$ was provide in all areas. Some areas were still dedicated for street vendors activities, bollards and vertical greenery that were installed on the several walls.

The second inclusive design principle implemented was Equitable but Reasonable Use. Siwalankerto Sidewalk was proposed with a $5 \mathrm{~cm}$ height difference to the road level. This recommendation was made considering the limited width of the sidewalk and requirement of 1:12 slope of curb ramps. Because of that, the curb ramps just needed $60 \mathrm{~cm}$ length.

Applying the second principle, sidewalks would also be equipped with guiding path in the center of the sidewalk. This would reduce the potential crossing with existing activities such as street vendors, bollards, fences, and other street furniture. The minimum of $1.50 \mathrm{~m}$ width of sidewalk was proposed for wheelchair maneuver and two persons walking side by side. Meanwhile the exit ramps for access to and from houses and shops was proposed. To improve pedestrian's safety and deterring illegal vehicle parking, some integrated bollard and street lamps, with $1.20 \mathrm{~m}$ height, were proposed to be placed at the sidewalk edge.

The third inclusive design principle adopted was Simple and Intuitive Use. To achieve it, guiding paths with international standards were proposed. Guiding path was a line to indicate the direction using a point-specific dots to give a warning to stop or caution.

The Low Physical Effort was the fourth principle of inclusive design to apply. The $5 \mathrm{~cm}$ level difference and curb ramps with slope of 1:12 were applied. This was to enable the easier wheelchair users' mobility from sidewalk to the road with $60 \mathrm{~cm}$ length ramp.

Last but not least, The Prohibition of Usage Error was also implemented. To give caution to visually impaired persons, at the edge of the sidewalk the yellow-and-grey line were drawn with spotlight paint. The paint would reflect at night, informing drivers and pedestrians of the boundary of the sidewalks and the road.

The fifth principle was applied with non-slippery flooring. Responding to Surabaya's seasonal high-rainfall, the ceramic that were used was the non-slippery ones with certain ceramic coatings. Those are the two main selected materials for the sidewalk floor component.

For the sidewalk material, Niro Granite Porcelain Tiles (Grandino Type) was proposed. The material had a slightly rough surface so it would prevent slipping. It was also important for crutch or walking stick users because of the material's good grip.

Some of the specifications of the tiles are:

i) The material's origin: Indonesia

ii) Material: Porcelain with rough finishing to prevent slippage

iii) Color: Beige, Maroon, Grigio, Nero 
iv) Size: $30 \mathrm{~cm} \times 30 \mathrm{~cm}$

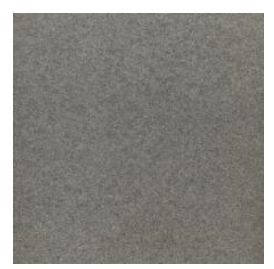

Fig. 13. The Non-slippery tiles Grandino Type, by the NiroGranito [13].

The guiding path material selection was important. The texture was important for the total blind disability persons, meanwhile the yellow colors for guiding the path and should be in contrast with the color of the sidewalk (so it could works for the low-vision users too). The guiding path specifications were:

i) Material's Origin: Shandong, China

ii) Material: PVC / TPU (Thermoplastic Polyurethane)/rubber/plastic

iii) Color: yellow, orange, gray, or be able to order

iv) Size: $30 \mathrm{~cm} \times 30 \mathrm{~cm}$

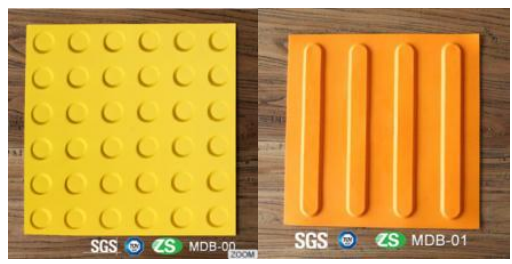

Fig. 14. The dotted-pattern and striped-pattern guiding path [14].

\section{Conclusion}

Sidewalks in Siwalankerto were not accessible for Persons with Disabilities. There were many barriers present such as: parked vehicle, trees, etc. The accessible sidewalk provision was not only the government's duty, but also all stakeholders' duty. The undergraduate students, as one of the stakeholders proposed a better sidewalk through the Service Learning (SL) Course. The SL also increase students' awareness, concern and contribution for Siwalankerto residents, especially the Persons with Disabilities.

The design would be disseminated to the Surabaya Municipality as well as Persons with Disabilities NGO to be widely implemented in many areas of Surabaya city. The current sidewalk design could be amended using this sidewalk model.

The authors would like to thank:

i) The DMU (General Education Department of PCU), Architectural Program of PCU.

ii) External partners such as: Institute Technology of Tenth of November (ITS), Department of Architecture, YPAB Surabaya (The Educational Foundation of Blind Children), YPAC Surabaya (The Educational Foundation of Disabled Children),

iii) Special thanks were given to Dr. Arina Hayati, Mr. Abdul Syakur S.E., Mr. Ahmad Fauzi M.Hum., Mrs, Lilik Ghoniyah Sofyan M.Ed., Mr. Tutus Setiawan M.Pd. and Mrs. Desy S.Pd..

iv) The Service Learning's Team: Dr. ir. Joyce Marcella Laurens, M.Arch., IAI, Ir. I Gusti Nyoman Sulendra,

v) The Service Learning's Students: Daniel Leite, Gabriel Reynard, Nicholas P.M., Vito Kosasih 


\section{References}

1. Republic of Indonesia. UU no 19 tahun 2011 tentang pengesahan convention in the rights of persons with disabilities/konvensi mengenai hak-hak penyandang disabilitas [Act no 19 Year 2011 on ratification on convention on the rights of persons with disabilities] [Online] from http://sipuu.setkab.go.id/PUUdoc/17346/UU0192011.pdf (2011). [Accessed on 28 Oktober 2017]

2. Republic of Indonesia. UU no 8 tahun 2016 tentang penyandang disabilitas [Act no 8 Year 2016 on persons with disabilities] [Online] from http://peraturan.go.id/uu/nomor8-tahun-2016.html (2016). [Accessed on 28 Oktober 2017]

3. Indonesian National Statistics Bureau (Badan Pusat Statistik Indonesia). Survey sosial dan ekonomi nasional 2001 [2001 national social and economic survey] [Online] from https://microdata.bps.go.id/mikrodata/index.php/catalog/43 (2001). [Accessed on 29 Oktober 2017].

4. I. Komardjaja, L.F.Tjong. The steps of sidewalks and public transport, and the heavy traffic of Bandung, Indonesia. 10th International Conference on Mobility and Transport for Elderly and Disabled People (Hamamatsu, Japan, 2004). Universal Transportation and Road Design: Strategies for Success (2004). https://trid.trb.org/View/890393

5. A. Munawar. Urban public transport policy in Indonesia. 10th International Conference on Mobility and Transport for Elderly and Disabled People (Hamamatsu, Japan, 2004). Universal Transportation and Road Design: Strategies for Success (2004). https://trid.trb.org/View/890548

6. B. Poerbantanoe. Laporan akhir penyusunan evaluasi rencana teknik ruang kota unit distrik Siwalankerto [Final report of technical evaluation of detail master planning in Siwalankerto district]. Indonesia: Dinas Cipta Karya dan Tata Ruang Kota Surabaya (2008).

7. H. Persson, H.Åhman, A.A.Yngling, J. Gulliksen. Universal Access in the Information Society, 14, 4:505-526 (2015). https://link.springer.com/article/10.1007/s10209-014$\underline{0358-\mathrm{Z}}$

8. C. Bühler. Universal Access in the Information Society, 1, 2, 85-90. (2001). https://link.springer.com/article/10.1007\%2Fs102090100011

9. A. Pirinen. International Journal of Design, 10, 3:27-42 (2016). http://www.ijdesign.org/index.php/IJDesign/article/view/2575

10. D. Levine (Eds). The NYC guidebook to accessibility and universal design [Online] from https://www1.nyc.gov/assets/ddc/downloads/publications/guidesmanuals/universal-design-ny.pdf (2003). [Accessed on 28 Oktober 2017]

11. Republic of Indonesia. Permen PU no 30/PRT/M/2006 tentang pedoman teknis aksesibilitas pada bangunan gedung dan lingkungan [Public works minister regulation no 30/PRT/M/2006 on technical guidelines on accessibility in building and environment] [Online] from http://regulation.lekslawyer.com/rahim/space/data/2006.12.01\%20Permen\%20PU\%20 No.\%2030_PRT_M_2006.pdf? (2006). [Accessed on 1 November 2017]. [in Bahasa Indonesia].

12. G. Tanuwidjaja. Desain rumah untuk hidup yang bermartabat [Living in dignity home design]. Surabaya: Program Studi Arsitektur, Universitas Kristen Petra (2015). [in Bahasa Indonesia]. http://repository.petra.ac.id/17681/ 
13. Niro Ceramic Group. Gradino [Online] from http://www.nirogranite.com/product.php? $\mathrm{a}=\& \mathrm{0}=\& \mathrm{i}=33 \& \mathrm{p}=3$ (2017). [Accessed on 15 November 2017].

14. Alibaba. Rubber tactile tile guide path rubber [Online] from http://www.alibaba.com/product-detail/Rubber-tactile-tile-guide-path-rubber 60334306539.html (2017). [Accessed on 10 November 2017]. 